\title{
EFFECT OF ADDING WATER-BASED BINDERS ON THE TECHNOLOGICAL PROPERTIES OF CERAMIC SLURRIES BASED ON SILICON CARBIDE
}

\author{
VPLIV DODATKA VODOTOPNEGA VEZIVA NA TEHNOLOŠKE \\ LASTNOSTI SUSPENZIJE SILICIJEVEGA KARBIDA
}

\author{
Paweł Wiśniewski, Marcin Małek, Jarosław Mizera, Krzysztof Jan Kurzydłowski \\ Warsaw University of Technology, Faculty of Materials Science and Engineering, 141 Woloska street, Warszawe, Poland \\ p.wisniewski@inmat.pw.edu.pl
}

Prejem rokopisa - received: 2015-07-02; sprejem za objavo - accepted for publication: 2016-03-07

doi: $10.17222 /$ mit.2015.194

\begin{abstract}
Presented is research work concerning the possibility of applying new materials for the preparation of ceramic shell moulds. Most of the methods for the fabrication of ceramic slurries for investment casting are based on alcohol binders. This is one of the first researches focused on the preparation of ceramic slurries using a new, ecological method based on water-soluble binders. The work presents the rheological properties of ceramic slurries based on silicon carbide and new binders, i.e., polyvinyl alcohol and two polyacrylic binders. The rheological properties of the investigated slurries were modified by the addition of $15 \%$ of mass fractions of the binders in the solution form. The solid phase content in the ceramic slurries was 62.5 $\%$ of mass fractions. Standard industrial parameters such as pH, density, Zhan 4\# Cup viscosity and apparent viscosity determined by a rheometer were studied. The grain size of the silicon carbide powder was determined by SEM observations. The ceramic slurries were fabricated using a mechanical mixer, and the mixing time was $96 \mathrm{~h}$. The results showed that the ceramic slurries were stable vs. time and met standard industrial requirements. The ceramic slurries have very promising properties and they are very promising for future shell moulds fabrication.
\end{abstract}

Keywords: ceramic shell moulds, silicon carbide, binder, rheological properties, ceramic slurries

Predstavljeno je raziskovalno delo o možnostih uporabe novih materialov za pripravo keramičnih form. Večina metod priprave keramične suspenzije za precizijsko litje temelji na alkoholnih vezivih. To je ena od prvih raziskav usmerjenih v pripravo keramičnih suspenzij, z uporabo nove, ekološke metode na osnovi vodotopnih veziv. Delo predstavlja reološke lastnosti keramičnih suspenzij na osnovi silicijevega karbida in novih veziv, kot je polivinil alkohol in dve poliakrilni vezivi. Reološke lastnosti preiskovanih suspenzij so bile spremenjene $\mathrm{z}$ doatkom 15 masnih \% veziv v obliki raztopine. Vsebnost trdne faze v keramični suspenziji je bila 62,5 masnih \%. Proučevani so bili običajni industrijski parametri kot: pH, gostota, viskoznost z Zhan 4\# Cup viskozimetrom in navidezna viskoznost, določena z reometrom. Velikost zrn silicijevega karbida je bila določena s SEM. Keramična suspenzija je bila izdelana s pomočjo mehanskega mešalnika, s časom mešanja 96 h. Rezultati so pokazali, da je suspenzija časovno stabilna in ustreza industrijskim zahtevam. Keramične suspenzije imajo obetajoče lastnosti in so zelo primerne za bodočo izdelavo školjkastih oblik.

Ključne besede: keramične školjkaste forme, silicijev karbid, vezivo, reološke lastnosti, keramične suspenzije

\section{INTRODUCTION}

Historically, investment-casting technology was mainly used for the casting of tools, weapons and ornaments. Nowadays, this technology is employed in many important manufacturing sectors, both industrial and artistic. ${ }^{1}$ Investment castings fabricated by the lostwax method are widely used in many fields of industry. Owing to their merits, including high quality, reliability, high Weibull modulus this method is the most popular in aircraft turbine parts manufacturing. ${ }^{2}$ European environmental regulations press the precision-casting industry for elimination of to eliminate alcohol binders from the moulds production process. From the beginning the process was based on ethyl silicate binders. According to the European regulations they should be fully replaced by water-based binders. Water systems need to contain polymers to improve the "green" state properties. The application of polymer-modified binders decreases the strength of moulds after burnout, but increases their permeability and flexibility. ${ }^{3-4}$

In comparison with other techniques of casting, investment casting has many advantages:

- obtaining the highest dimensional accuracy and surface smoothness,

- replacing expensive machining methods to fabrication precision castings,

- possibility of obtaining castings with very complex shapes, which cannot be achieved by other methods,

- possibility of casting of any alloy (in mass production and high volume),

- thin-walled castings can be achieved.

Disadvantages of the process:

- difficult process for mechanization and automation,

- limited casting weight substantially to $1-2 \mathrm{~kg}$, particularly to $10 \mathrm{~kg} .{ }^{5-7}$

Silicon carbide is widely used in many industrial areas due to its properties and low cost. New research 
P. WIŚNIEWSKI et al.: EFFECT OF ADDING WATER-BASED BINDERS ON THE TECHNOLOGICAL PROPERTIES ...

showed that its application in ceramic shell moulds improves the technological parameters of the shells, such as: mechanical strength, thermal conductivity and thermal shock resistance. Shell moulds containing $\mathrm{SiC}$ powder significantly shortened the process of the fabrication of the final cast, reduced grain size of the castings and improved its mechanical properties..$^{8-11}$

\section{EXPERIMENTAL PART AND METHODOLOGY}

The studies were carried out on silicon carbide powder (Stanchem, Poland). In addition, three different water-soluble binders were used i.e., polyvinyl alcohol (26000 g/mol weight and $88 \%$ hydrolysis content (PVAL), Moviol, Germany), and two polyacrylic binders with $20 \%$ of mass fractions (PA) and $40 \%$ of mass fractions (PA2) of vinyl acrylic copolymer (Ransom \& Randolph, USA) as $10 \%$ water solution. The main binder was a substance with nanoparticles of aluminium oxide (Evonik, Germany). The SiC powder content in the slurry was $62.5 \%$ of mass fractions. SEM images of the SiC powder were taken using a SU70 Hitachi microscope (Japan). Grain size was measured on La-950 Horiba analyser (Japan). The ceramic slurries were fabricated in a reactor with a mechanical mixer. The ceramic slurries were characterized using a Zahn Cup 4\#, aerometer, plate weight test (adhesion test) and $\mathrm{pH}$ meter. The plate weight test time (120 s) was elaborated by the authors and determined the stable properties of the researched ceramic slurries (experience from past studies). The apparent viscosity was determined using a DV II+ Brookfield rheometer (USA). The rheological properties were tested in the speed range 20-200-20 $\min ^{-1}$.

\section{RESULTS AND DISCUSSION}

Figure 1 presents the SEM image of the investigated silicon carbide power. SiC was characterized by sharpedged particles typical for moldings powders. The

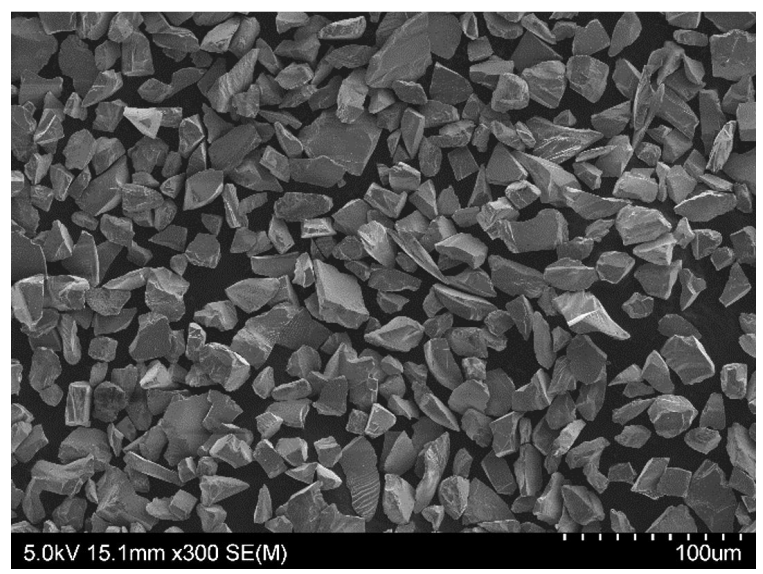

Figure 1: SEM image of investigated SiC powder

Slika 1: SEM-posnetek preiskovanega SiC prahu average equivalent diameter of the $\mathrm{SiC}$ grains was 21.9 $\mu \mathrm{m}$.

Figures 2 to 4 presents adhesion test results of the ceramic slurries based on $\mathrm{SiC}$. As seen in all the presented graphs, the highest weight loss occurred during the first day of the experiment. The rest of the curves were similar. A plateau was observed at $80 \mathrm{~s}$ for the PA(Figure 2) for PA2 the plateau occured at $110 \mathrm{~s}$ (Figure 3) and for PVAL was also at $80 \mathrm{~s}$ (Figure 4). The time of the plateau's appearance depended on the viscosity and density of the ceramic slurries.

Figure 5 shows the apparent viscosity of the examined ceramic slurries. The highest viscosity was exhibited by a slurry with $15 \%$ of mass fractions addition of

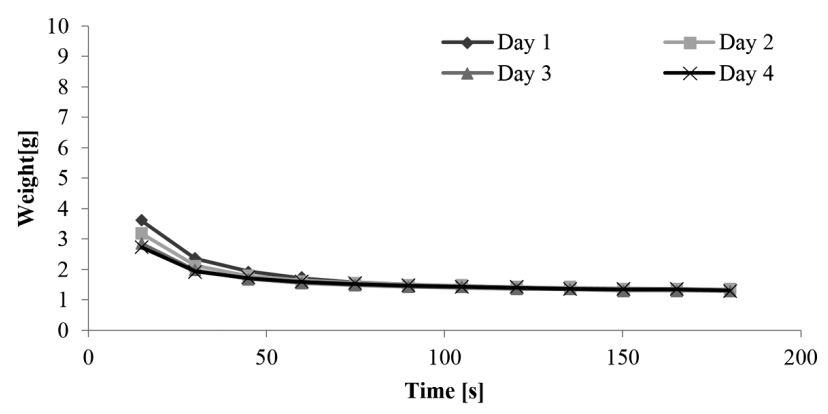

Figure 2: Results of plate weight test of slurry with $15 \%$ of mass fractions of PA

Slika 2: Rezultati preizkusa adhezije suspenzije s $15 \%$ masnih deležev PA

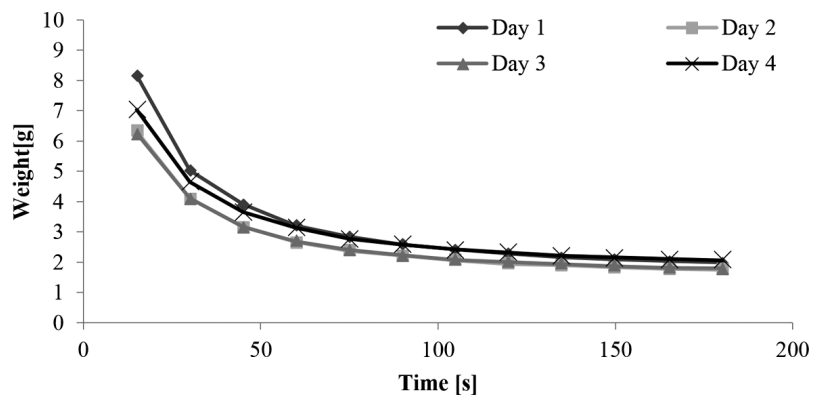

Figure 3: Results of plate weight test of slurry with $15 \%$ of mass fractions of PA2

Slika 3: Rezultati preizkusa adhezije suspenzije s $15 \%$ masnih deležev PA2

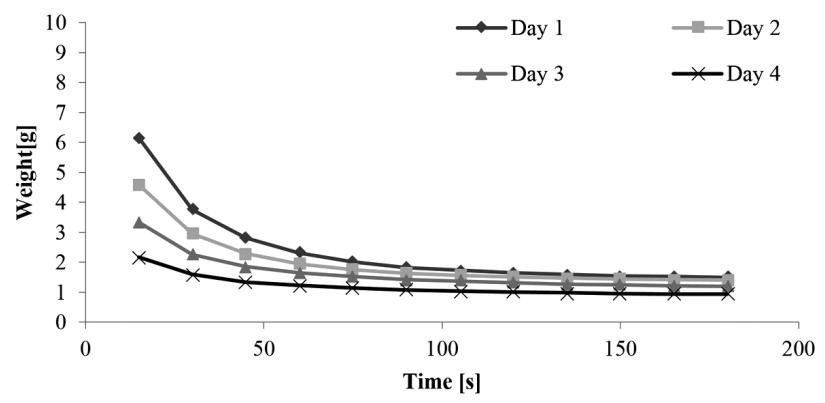

Figure 4: Results of plate weight test of slurry with $15 \%$ of mass fractions of PVAL

Slika 4: Rezultati preizkusa adhezije suspenzije s $15 \%$ masnih deležev PVAL 


\section{P. WIŚNIEWSKI et al.: EFFECT OF ADDING WATER-BASED BINDERS ON THE TECHNOLOGICAL PROPERTIES ..}

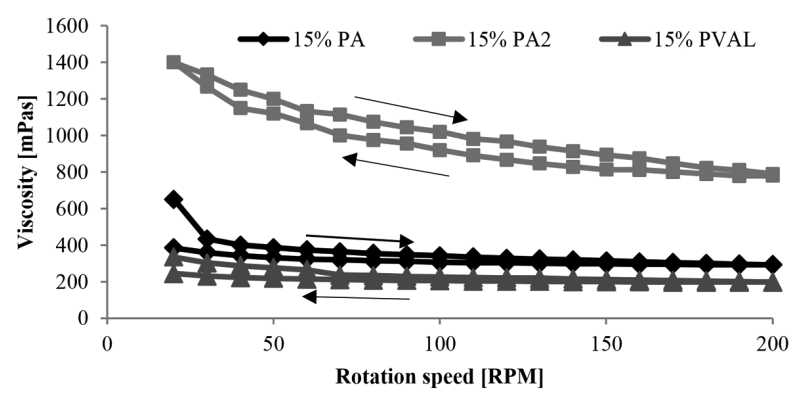

Figure 5: Apparent viscosity of the ceramic slurries Slika 5: Navidezna viskoznost keramične suspenzije

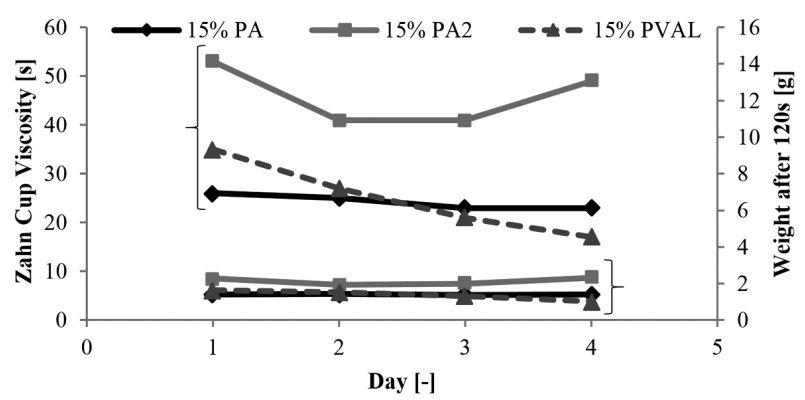

Figure 6: Rheological properties of the ceramic slurries

Slika 6: Reološke lastnosti keramičnih suspenzij

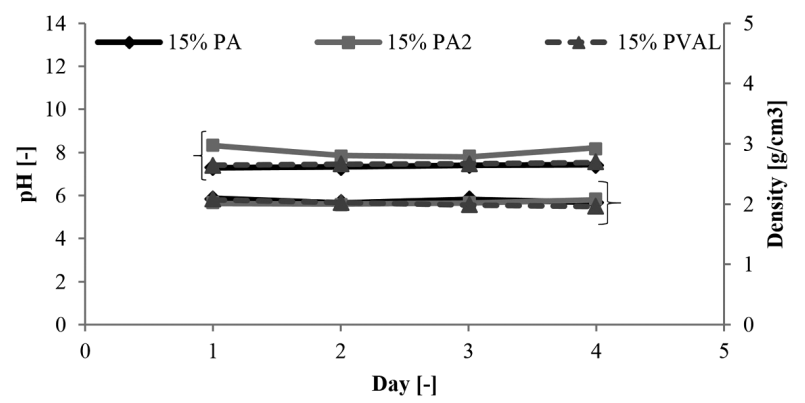

Figure 7: Density and $\mathrm{pH}$ of the ceramic slurries

Slika 7: Gostota in $\mathrm{pH}$ keramičnih suspenzij

PA2, while the lowest viscosity had the slurry with $15 \%$ of mass fractions PVAL.

Figure 6 presents the basic rheological properties of the ceramic slurries. The addition of $15 \%$ of mass fractions of PA2 and PVAL were inappropriate, because the viscosity of such slurries was high. A ceramic slurry with $15 \%$ of mass fractions of PA met the standard industrial requirements. Its viscosity had the optimal value and slightly decreased with time. The results of the plate weight test made on daily basis were very comparable for all types of slurries.

Figure 7 shows the $\mathrm{pH}$ and density results of the examined ceramic slurries. The described properties were stable over time, and similar for all types of slurries.

\section{CONCLUSIONS}

According to the work assumption, with connection to the industrial requirements, these researches were focused on the rheological and technological properties of ceramic slurries based on silicon carbide powder. The main aim of this work was to fabricate ceramic slurries by using new water-soluble binders. The most desirable properties from the industry point of view were exhibited by the slurry with a $15 \mathrm{wt} . \%$ addition of PA binder. The slurries with PA binder were characterized by relatively low viscosity, the best adhesion and stability confirmed by the plate weight test. The research conducted in this work is the first in the world and has a very promising future in ceramic shell moulds fabrication.

\section{Acknowledgments}

Financial support of Structural Funds in the Operational Programme - Innovative Economy (IE OP) financed from the European Regional Development Fund - Project "Modern material technologies in aerospace industry", No. POIG.01.01.02-00-015/08-00 is gratefully acknowledged.

\section{REFERENCES}

${ }^{1}$ S. Rzadkosz, J. Zych, A. Garbacz-Klempka, M. Kranc, J. Kozana, M. Piekos, J. Kolczyk, L. Jamrozowicz, T. Stolarczyk, Copper alloys in investment casting technology, Metalurgia 54 (2015), 293-296

${ }^{2}$ J. Tomasik, R. Haratym, R. Biernacki, Investment casting or powder metallurgy- the ecological aspect, Archives of Foundry Engineering, 9 (2009) 2, 165-168

${ }^{3}$ A. Tyrek, J. Nawrocki, D. Sarek, Lost wax process - mould properties, Archives of Fundry and Engineering, 10 (2010) 1, 427-430

${ }^{4}$ M. Nadolski, Z. Konopka, M. Lagiewka, A. Zyska, Examining of slurries and production of moulds by spraying method in lost was technology, Archives of Fundry and Engineering, 8 (2008) 2, 107-110

${ }^{5}$ R. Haratym, R. Biernacki, D. Myszka, Ekologiczne wytwarzanie dokładnych odlewów w formach ceramicznych, Oficyna Wydawnicza Politechniki Warszawskiej, (2008), 25-47

${ }^{6}$ H. Matysiak, J. Ferenc, J. Michalski, Z. Lipinski, G. Jakubowicz, K. J. Kurzydlowski, Porosity and strength of ceramic shells used in Bridgman investment casting process, Materials Engineering 1 (2011), 17-21

${ }^{7}$ M. R. Ismael, R. D. dos Anjos, R. Salomao, V.C. Pandolfelli, Colloidal silica as a nostructured binder for refractory castables, Refractories Applications and News 11 (2006) 4, 16-20

${ }^{8}$ M. Malek, P. Wisniewski, H. Matysiak, R. Sitek, K. J. Kurzydlowski, Effect of polyethylene glycol addition on ceramic slurry properties used in investment casting, Polymer Processing 157 (2014) 20, 40-49

${ }^{9}$ M. Malek, J. Szymanska, P. Wisniewski, J. Mizera, K.J. Kurzydlowski, Technological properties of silicon carbide ceramic slurries for fabrication ceramic shell moulds, Proc. of the 5-th Aluminium 2000 Confeence, Florence, 2015, 1-8

${ }^{10}$ M. Malek, P. Wisniewski, J. Mizera, K.J. Kurzydlowski, Technological Technological properties of ceramic slurries based on silicon carbide for manufacturing ceramic shell moulds, Materials Engineering, 6 (2015) 208, 561-564

${ }^{11}$ M. Malek, P. Wisniewski, H. Matysiak, K.J. Kurzydlowski, Slurries for ceramic shell moulds fabrication, patent application no. P.406518, 2013 